\title{
MATERNAL IMMUNIZATION TO PATERNAL ANTIGENS IN MULTIPAROUS MICE
}

\author{
M. G. BAINES, ${ }^{*}$ J. ANSELL, $\dagger$ A. MaLAREN AND H. S. MICKLEM \\ Departments of Zoolog' and Animal Genetics, University of Edinburgh
}

(Received 24th Fune 1974)

\begin{abstract}
Summary. Mice of the CBA strain which had given birth to five litters sired by males of a different $\mathrm{H}-2$ type (C57BL/10) showed evidence of immunization to paternal antigens, in that the numbers of lymphocytes forming alloclusters with paternal erythrocytes were significantly elevated. On the other hand, the graft-versus-host responsiveness of maternal splenic lymphocytes to paternal antigens remained virtually unchanged, showing only a slight increase at Day 8 of the assay.
\end{abstract}

\section{INTRODUCTION}

The immunological relationship between the mother and the developing fetus is complex and is not as yet fully understood. There is evidence of the development of cellular sensitization of the multiparous female against paternal antigens (Sören, 1967; Maroni \& Parrott, 1973; Butsch, Meeker \& Grace, 1969), but little or no evidence that such events have any adverse effect on fetal development (Hašková, 1961; Clarke, 1971; Beer \& Billingham, 1971). Experimental immunization of female rats with paternal antigens may result in runt disease after birth (Beer, Billingham \& Yang, 1972; Beer \& Billingham, 1973). The present experiments were designed to look for evidence of immunization by paternal antigens in normal multiparous female mice differing from the male at a strong histocompatibility locus. Two assays were used: the cluster (rosette) assay for lymphocytes specifically recognizing paternal-strain erythrocytes (Micklem, Asfi, Staines \& Anderson, 1970), and a modification of the localized graft-versus-host (GVH) assay (Ford, Burr \& Simonsen, 1970).

\section{MATERIALS AND METHODS}

Two-month-old CBA/H and C57BL/10 (B10) mice were reciprocally mated for four or five successive pregnancies. Two assays for immunization to paternal antigens were performed. Negative controls consisted of parallel assays on agematched virgin female mice and $\mathrm{CBA} / \mathrm{H}$ females multiparous by syngeneic males. The negative control data were pooled, as similar results were seen in both groups.

\footnotetext{
* Present address: Department of Obstetrics and Gynaecology, Queen's University, Kingston, Ontario, Canada.

$\dagger$ Present address: A.R.C. Unit of Reproductive Physiology and Biochemistry, Huntingdon Road Cambridge.
} 
Cluster (rosette) assay

As described by Micklem \& Anderson (1972), $5 \times 10^{6}$ spleen lymphocytes freed of erythrocytes by a wash in tris-buffered ammonium chloride (Boyle, 1968) were rolled overnight at $4^{\circ} \mathrm{C}$ in phosphate-buffered saline, $\mathrm{pH} 7 \cdot 2$, containing $1 \%$ normal serum of the maternal strain, with $15 \times 10^{6}$ red blood cells from either syn-, allo- or xenogeneic sources. The normal maternal serum was previously absorbed for $30 \mathrm{~min}$ at $37^{\circ} \mathrm{C}$ with $\frac{1}{10}$ vol. of both packed paternal erythrocytes and sheep red blood cells.

A modification of the reading procedure was employed as follows. Permanent glass-slide chambers were constructed using a catalysed resin adhesive to attach strips of No. 1 coverslips to the slide to make two chambers/slide (Text-fig. 1).

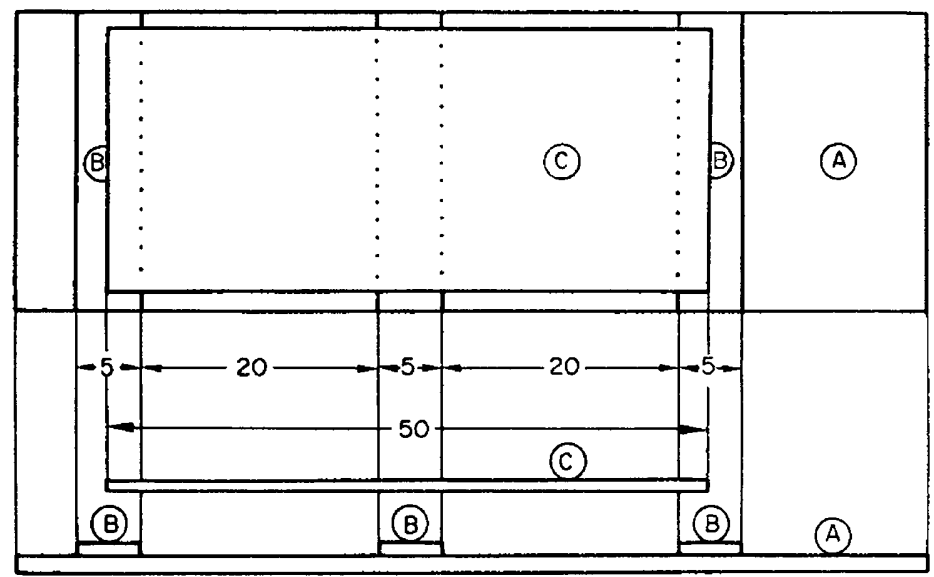

Text-Fig. 1. Diagram of the permanent precalibrated rosette counting chamber. A, standard glass slide, $75 \times 25 \mathrm{~mm}$; B, three strips of No. 1 coverglass; G, No. 3 coverglass, $22 \times 50 \mathrm{~mm}$.

The dimensions were approximately $25 \mathrm{~mm} \times 20 \mathrm{~mm} \times 0.15$ to $0.20 \mathrm{~mm}$, the depth being accurately measured by a micrometer and etched onto the end of the slide. The chamber dividers were lubricated with pure mineral oil and a No. 3 coverslip was placed on top. Before pipetting $50 \mu \mathrm{l}$ of the suspension into a chamber, $2 \mu$ l fluorescein diacetate solution $(5 \mathrm{mg} / \mathrm{ml}$ acetone) was added for each $\mathrm{ml}$ of cell suspension to allow an estimation of viability (Rotman \& Papermaster, 1966). The edges of the chamber were then sealed with mineral oil to prevent evaporation. Total and viable cell counts were then made under tungsten and blue-violet illumination, respectively, utilizing a precalibrated eye-piece grid and the measured depth correction factor. The suspensions were scanned for clusters at $\times 200$ magnification and the presence of a viable yellowgreen fluorescent lymphocyte in the cluster was verified. Leucocyte morphology and the number of bound erythrocytes were determined at $\times 400$ to 600 magnification.

\section{Graft-versus-host assay}

The reactivity of the thymus-derived $(\mathrm{T})$ cell population was assessed by a 
modification of the local assay of Ford et al. (1970). Spleen lymphocytes $\left(5 \times 10^{6}\right)$ from a maternal-strain donor were injected into the left rear foot pads of groups of at least four 2-month old $F_{1}$ hybrids of the maternal and paternal strains. 'The hybrid mice were given an intraperitoneal injection of $5 \times 10^{-8}$ ${ }^{\mathrm{M}}$-5-fluoro-2'deoxyuridine 4 or 8 days later. After $1 \mathrm{hr}, 1 \mu \mathrm{Ci}$ of $\left[{ }^{125} \mathrm{I}\right] 5$-iodo2 'deoxyuridine was similarly injected. The left and right popliteal nodes were excised $2 \mathrm{hr}$ later and were fixed in $4 \%$ formaldehyde- $70 \%$ ethanol. After washing in $70 \%$ ethanol, the nodes were counted in a Packard Autogamma Scintillation Counter. Uptake was expressed as the ratio of counts in the left (experimental) lymph node to the counts in the right (control) lymph node.

\section{RESULTS}

The results of cluster assays on multiparous mice, tested within 20 days after the end of the final pregnancy, and on control mice, are shown in Table 1. The number of allo-(paternal) reactive cluster-forming lymphocytes was elevated in GBA and B10 females that had given birth to five litters sired by the allogeneic paternal strain. The results for the two combinations did not differ significantly from one another, though the increase in allocluster-forming cells only reached the $5 \%$ level of significance in the CBA females. The combined increase was significant at the $2 \%$ level. Normal CBA mice showed a similar elevation of allocluster-forming cells after a skin allograft (Table 1 ). The frequencies of syn(maternal) and xeno- (sheep erythrocyte) cluster-forming lymphocytes were not increased after five pregnancies (Table 2).

There was no significant difference in the GVH responsiveness of multiparous maternal lymphocytes compared to that of lymphocytes from control mice as assayed at Day 4 after inoculation into the $F_{1}$ hybrid recipient (Table 3). The Day-8 assay did suggest an increased responsiveness of lymphocytes from multiparous CBA females. Although statistically significant at the $5 \%$ level, the increase was counterbalanced by a slightly decreased reactivity in the Day-4 assay.

\section{DISCUSSION}

In principle, immunization of the mother to paternal antigens derived from the fetus could involve T-lymphocytes, B-lymphocytes, or both. The GVH assay may be assumed to reflect primarily T-lymphocyte activity. Our data show no clearly significant evidence of increased GVH reactivity in the spleen cells of multiparous mice. By contrast, Maroni \& Parrott (1973), using a basically similar GVH assay, showed progressively increasing reactivity in CBA females which had borne one to five litters sired by AKR males. This difference may be explained by two differences in the experimental design. (1) In addition to spleen, Maroni \& Parrott (1973) used lymph nodes draining the uterus as a source of lymphocytes; these lymph nodes might be expected to be more strongly sensitized. (2) Our strain combination involved a difference at the H-2 locus, while in the experiments of Maroni \& Parrott (1973) both strains were $\mathrm{H}-2^{\mathbf{k}}$, histoincompatibility residing only in the relatively 'weak' antigens 


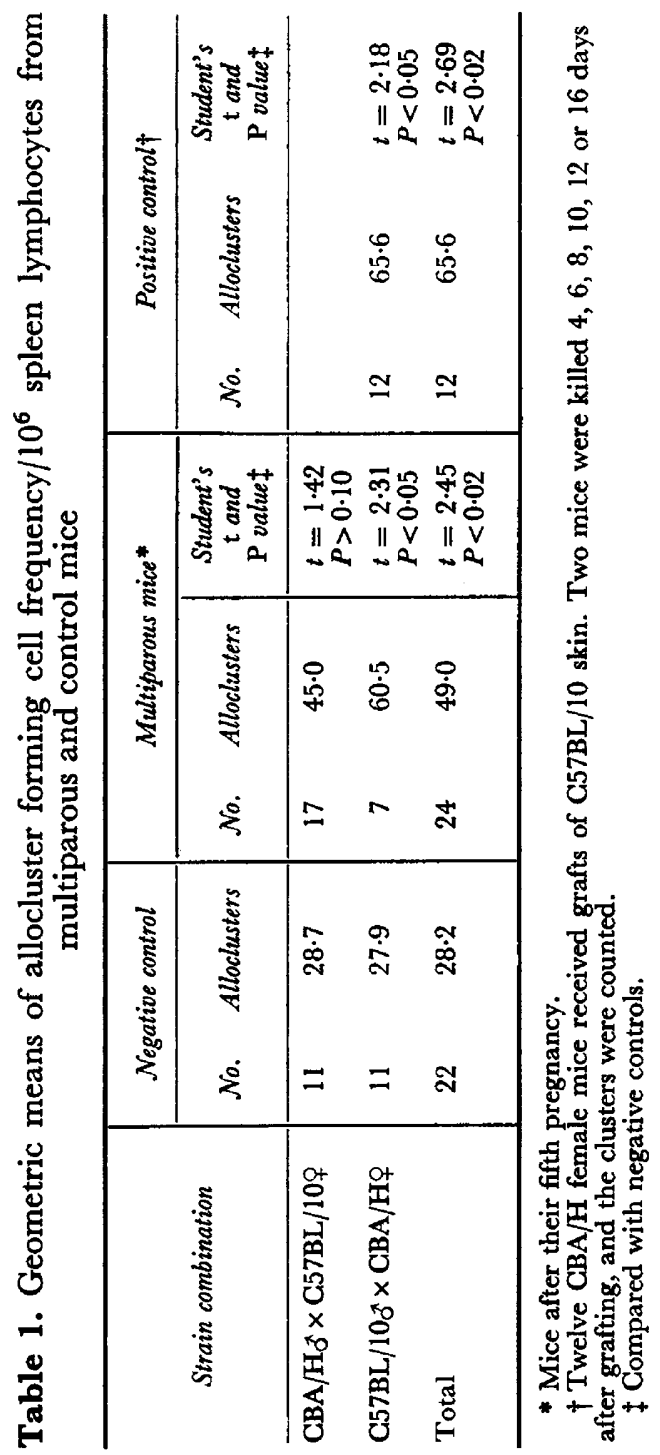


Table 2. Geometric mean frequencies of cluster forming lymphocytes from multiparous and control mice of both mating combinations

\begin{tabular}{|c|c|c|c|}
\hline \multirow[b]{2}{*}{ Group } & \multicolumn{3}{|c|}{$\begin{array}{c}\text { Cluster type and frequency } / 10^{6} \text { viable spleen } \\
\text { lymphocytes }\end{array}$} \\
\hline & $\begin{array}{c}\text { Synclusters } \\
(\text { Maternal } R B C)\end{array}$ & $\begin{array}{c}\text { Alloclusters } \\
(\text { Paternal } R B C)\end{array}$ & $\begin{array}{l}\text { Xenoclusters } \\
\text { (Sheep } R B C)\end{array}$ \\
\hline $\begin{array}{l}\text { Multiparous } \\
\text { Control } \\
\text { Student's } t \\
\text { Significance }\end{array}$ & $\begin{array}{c}35.5 \\
24 \cdot 3 \\
t_{38}=1 \cdot 50 \\
P>0.10\end{array}$ & $\begin{array}{c}49.0 \\
28.2 \\
t_{44}=2.45 \\
P<0.02\end{array}$ & $\begin{array}{c}218.8 \\
222.5 \\
t_{38}=0.10 \\
P>0.9\end{array}$ \\
\hline
\end{tabular}

Further details of the mice, and of the allocluster scores, are given in Table 1 .

Table 3. Local graft-versus-host response of control and multiparous maternal spleen lymphocytes in 2-month-old hybrid recipient mice

\begin{tabular}{|c|c|c|c|c|}
\hline \multirow[t]{2}{*}{ Donor } & \multirow[t]{2}{*}{$\begin{array}{c}\text { Day of } \\
\text { assay }\end{array}$} & \multicolumn{2}{|c|}{$\begin{array}{c}\text { Ratio of uptake in popliteal lymph nodes } \\
\text { after injection of lymphocytes from } \\
\text { spleen of: }\end{array}$} & \multirow[t]{2}{*}{$\begin{array}{l}\text { Student's } \mathrm{t} \text { and } \\
\mathrm{P} \text { value }\end{array}$} \\
\hline & & Control mice & Multiparous mice & \\
\hline \multirow[t]{2}{*}{ C57BL/10 (H-2 $\left.{ }^{b}\right)$} & 4 & $\begin{array}{c}0.29 \pm 0.04 \\
(1.95)\end{array}$ & $\begin{array}{c}0.38 \pm 0.03 \\
(2.39)\end{array}$ & $t_{102}=1.75, P>0.05$ \\
\hline & 8 & $\begin{array}{c}0.30 \pm 0.06 \\
(1.99)\end{array}$ & Not done & 一 \\
\hline \multirow[t]{2}{*}{ GBA/H $\left(\mathbf{H}-2^{\mathbf{k}}\right)$} & 4 & $\begin{array}{c}0.55 \pm 0.04 \\
(3.51)\end{array}$ & $\begin{array}{c}0.46 \pm 0.06 \\
(2.87)\end{array}$ & \\
\hline & 8 & $\begin{array}{c}0.37 \pm 0.06 \\
(2.35)\end{array}$ & $\begin{array}{c}0.55 \pm 0.06 \\
(3.51)\end{array}$ & $t_{28}=2.06, P<0.05$ \\
\hline
\end{tabular}

The hybrids were $\mathrm{G} 57 \mathrm{BL} / 10 \times \mathrm{GBA} / \mathrm{H} \mathrm{F}_{1}\left(\mathrm{H}-2^{\mathrm{bk}}\right)$ and the response was measured by uptake of $\left[{ }^{125} \mathrm{I}\right] 5$-iodo-2'deoxyuridine. Values are given as the logarithmic mean \pm one S.E. Figures in parentheses represent the antilogarithm of the mean uptake ratio.

determined by other H-loci. It has long been known that the effect of immunization on GVH reactivity is much greater in weakly histoincompatible strain combinations than in combinations in which a strong $\mathrm{H}-2$ incompatibility exists (Simonsen, 1962; Loutit \& Micklem, 1962).

Lymphocytes specifically forming clusters with donor-strain erythrocytes (allocluster-forming cells) have been described in the regional lymph nodes of mice with skin allografts (Micklem et al., 1970; Viklický, Lengerová, Matoušek \& Boubelik, 1971). The present results show that such cells are also to be found in the spleens of mice with skin allografts and, in comparable numbers, of multiparous mice. It is not yet certain whether allocluster-forming cells belong to the T-lymphocyte or B-lymphocyte population or to both. Evidence on the sensitivity to anti-theta serum of 'background' syncluster-forming cells in normal mouse lymph nodes (Micklem \& Anderson, 1972) and of alloclusterforming cells in mice with skin allografts (M. Boubelík, M. Rose \& V. Viklický, personal communication) suggests that many, if not all, are B-cells. The same conclusion has recently been reached by Brondz, Kotomina, Jeliseyeva, 
Egorova \& Snegiröva (1973). This would be consistent with the presence of the haemagglutinating antibodies to paternal antigens noted by previous authors (Goodlin \& Herzenberg, 1964; Kaliss \& Dagg, 1964).

The data are compatible with the view, derived from the results of several authors, that maternal sensitization to paternal antigens of the fetus occurs frequently in mice (Sörén, 1967; Maroni \& Parrott, 1973), but that its effects do not normally include an accelerated rejection of paternal skin grafts during pregnancy or damage to the developing fetus (Breyere \& Barrett, 1960; Prehn, 1960). This failure to express the state of sensitivity is probably due to the coincidental development of enhancing or blocking antibodies (Kaliss \& Dagg, 1964; Hellström, Hellström \& Brawn, 1969). A possible explanation of the observed increase in the number of allocluster-forming lymphocytes is that they are involved in the production of such blocking factors.

\section{ACKNOWLEDGMENTS}

We should like to acknowledge financial assistance from the Medical Research Council (H.S.M. and M.G.B.) and from the Ford Foundation (A.McL.). One of us (J.A.) was in receipt of a Ministry of Agriculture, Fisheries and Food Postgraduate Studentship.

\section{REFERENCES}

Beer, A. E. \& Billingham, R. E. (1971) Immunobiology of mammalian reproduction. Adv. Immunol. 14, 1-84.

BeER, A. E. \& Bil.ringham, R. E. (1973) Maternally acquired runt disease. Science, $\mathcal{N}$. Y. 179, 240-243.

BeER, A. E., BILlingham, R. E. \& YANG, S. L. (1972) Maternally induced transplantation immunity, tolerance and runt disease in rats. F. exp. Med. 135, 808-826.

Boyle, W. (1968) An extension of the ${ }^{51}$ Cr-release assay for the estimation of mouse cytotoxins. Transplantation, 6, 761 .

Breyere, E. J. \& BARRetT, M. K. (1960) 'Tolerance' in postpartum female mice induced by strainspecific matings. F. natn. Cancer Inst. 24, 699.

Brondz, B. D., Kotomina, I. F., Jeliseyeva, L. S., Egorova, S. G. \& Snegiröva, A. E. (1973) Relalationship between killer and rosette-forming cells reactive to H-2 antigens. Scand. F. Immunol. $2,463-477$.

Butsch, D. W., MEeker, W. R. \& GRAGE, J. T. (1969) Immunologic considerations of fetal survival in mice. F. Surg. Oncol. 1, 357-368.

Glarke, A. G. (1971) The effect of maternal pre-immunization on pregnancy in the mouse. $\mathcal{F}$. Reprod. Fert. 24, 369-375.

Ford, W. F., BURR, W. \& Simonsen, M. (1970) A lymph node weight assay for the graft-versus-host activity of rat lymphoid cells. Transplantation, 10, 258.

Goodurn, R. G. \& Herzenberg, L. A. (1964) Pregnancy induced haemagglutinins to paternal H-2 antigens in multiparous mice. Transplantation, 2, 357-361.

HAšKovÁ, V. (1961) Relationship between tissues of mother and foetus and tissue incompatibility. Folia biol., Praha, 7, 322.

Hellström, K. E., Heliström, I. \& BRAwN, J. (1969) Abrogation of cellular immunity to antigenically foreign mouse embryonic cells as a serum factor. Nature, Lond. 224, 914-915.

KALISs, N. \& DAGG, M. K. (1964) Immune response engendered in mice by multiparity. Transplantation, $2,416-425$.

Loutit, J. F. \& Micklem, H. S. (1962) 'Secondary disease' among lethally irradiated mice restored with haematopoietic tissues from normal or isoimmunized foreign mice. Br. F. exp. Path. 43, 7787.

Maroni, E. S. \& Parrotr, D. M. V. (1973) Progressive increase in cell-mediated immunity against paternal transplantation antigens in parous mice after multiple pregnancies. Clin. exp. Immunol. 13, 253-262. 
Mickiem, H. S. \& Anderson, N. (1972) The cluster (rosette) assay for lymphocytes binding syngeneic and sheep erythrocytes; some important variables. In Cell Interactions, pp. 229-236. Ed. L. G. Silvestri. North Holland, Amsterdam.

Micklem, H. S., Asfi, C., Staines, N. A. \& Anderson, N. (1970) Quantitative study of cells reacting to skin allografts. Nature, Lond. 227, 947-949.

Prefi, R. T. (1960) Specific homograft tolerance induced by successive matings and implications concerning choriocarcinoma. F. natn. Cancer Inst. 25, 883-886.

Rotman, B. \& Papermaster, B. W. (1966) Membrane properties of living mammalian cells as studied by enzymatic hydrolysis of fluorogenic esters. Proc. natn. Acad. Sci. U.S.A. 55, 134-141.

Simonsen, M. (1962) The factor of immunization: clonal selection theory investigated by spleen assays of graft-versus-host reaction. In Transplantation, pp. 185-209. Ciba Foundation Symposium. Eds. G. E. W. Wolstenholme and M. P. Cameron. Churchill, London.

SörÉN, L. (1967) Immunological reactivity of lymphocytes in multiparous females after strain specific matings. Nature, Lond. 213, 621-622.

Vikicický, V., Lengerová, A., Matoušek, V. \& Boubelík, M. (1971) The frequency of 'alloclusterforming cells' in the lymph nodes of skin-grafted mice as a function of the histocompatibility barrier. Folia biol., Praha, 17, 156-162. 